\title{
The Impact of Reducing Mathematics Component in Biology "O" Level Examinations on Student's Performance in Mathematical Related Biology Courses at Diploma Level in Zambia
}

\author{
Kasongo Emmanuel ${ }^{1} \quad$ Elizabeth Boby Samuel $^{2 *} \quad$ Boby Samuel $^{3}$ \\ 1.Mutende Secondary School, Mansa, Luapula Province, Zambia \\ 2.The Copperbelt University, School of Mathematics and Natural Sciences, Department of Mathematics, Kitwe, \\ Zambia \\ 3.The Copperbelt University, School of Mathematics and Natural Sciences, Department of Biological Sciences, \\ Kitwe, Zambia
}

\begin{abstract}
Mathematics has played important roles in many fields of biology, and can be a powerful tool for understanding biological observed phenomena which cannot be understood by verbal reasoning alone. Quantitative questions in Zambian Biology O level examinations has kept on reducing irrespective of its importance in higher level biology courses. Therefore, this study aimed at determining the effect of reducing mathematics component in biology "O" Level examinations on students' performance in mathematical related biology courses at diploma level. Primary data was collected using five point Likert scale questionnaire and assessment test for mathematical biology. Secondary data was collected from Zambian, Cambridge and Edexcel biology "O" Level examination question papers from 1999-2017, Syllabi for Biology and examination results for mathematical biology related courses at diploma Level.The sample size for the study was 200 education and pharmacology students from Mansa School of Nursing and Zambia College of Open and Distance Learning and 50 teachers and examiners from the surrounding schools of Mansa District. The analysis of biology papers for the three examining bodies have revealed that International examinations had more mathematics component and it was consistent from 1999 to 2017 whilst in Zambian had less and kept on reducing from 2008 to 2017. Further, the syllabi for these examining bodies revealed that key aims and objectives are the same except that Zambian (Curriculum Development Centre) had no assessment objective weightings. The assessment test results analyzed using independent sample t-test at 0.05 level of significance revealed that students who did biology with more mathematics component performed better in mathematical related biology courses compared to the one with less mathematics component at diploma level. Further, the comparison of means of the results of pharmacology and biology education at diploma level also agreed with the outcome of the sample test.From the analysis of questionnaires for biology teachers and examiners revealed that pupil's attitude and performance in mathematics related biology questions and the general failure rate in biology had led to the reducing of mathematics component in Zambian biology.
\end{abstract}

DOI: $10.7176 / \mathrm{JEP} / 12-30-09$

Publication date:October $31^{\text {st }} 2021$

\subsection{Introduction}

It is clear that an improved understanding of biological systems leads at least indirectly to improved medical cases. However, there are many cases in which mathematics have a direct impact on medical sciences and in the $21^{\text {st }}$ century there is high demand of quantitative competencies for analysing data at higher level and Mathematics can be such a powerful tool for understanding biological observed phenomena which cannot be understood by verbal reasoning alone. One such example is that of homeostasis. Mathematicians and Biologists, including Medical Scientists, have a long history of working successfully together. Examples are given by the development of stochastic processes and statistical methods to solve a variety of population problems in demography, ecology, genetics and epidemics.

In addition, data collection capabilities have expanded enormously and continue to do so, and the mathematical biological sciences are innately involved in distilling knowledge from all those data. However, mechanisms to facilitate linkages between mathematical biological scientists and researchers in other disciplines must be improved. It is critical for the mathematical biological sciences community to play a role, through education research and collaboration. People with mathematical biological science background can bring different perspectives that complement others and can be very powerful tool for understanding and transforming the world.

Students' background performance is the leading factor in the poor performance of students at higher level. The researcher found that there was a link between perceived usefulness of an additional course and the performance of students in a current course. From this study one can tell that the background of students' performance in any given course can have far reaching effects on the performance of a related course of study. Blooms taxonomy noted that students' domain specifically the lower domain knowledge level is linked to their inside motivation or impetus to study a subject which in future will give them hope to their course preference and 
academic preparedness. Therefore, background academic performance is one of the reasons why good students choose programmes of study they are familiar with or have good background knowledge about.

The teaching of mathematics and biology separately makes pupils to face difficulties in making positive correlations between the two subjects and it becomes difficult for the pupils to understand how each subject influences the other Elizabeth et al (2017). Good mathematical understanding gives accuracy for analysing and interpreting biological data. Many studies have demonstrated that integrating more mathematics or statistics into biology coursework can lead to an increase in the students' quantitative or analytical ability. Hence, the reducing of mathematical component in biology "O" level will have a greater impact on students' performance in mathematical biological related courses at diploma level.

Biology and Mathematics are two Secondary School subjects which are the bedrock upon which an understanding of pharmacology and biology education should be built therefore, competence in biology and mathematics should be made pre- requisite at secondary school. From the Pharmacology department the examination results analysis showed that the students have not been doing very well in Pharmacology course in the successful years and this could be attributed to less mathematical biology content in Zambian O Level biology. This study, therefore aimed to determine the effect of reducing mathematics component in biology "O" Level examinations on students' performance in mathematical related biology courses at diploma level. The objectives of the study were:

1. To find out whether the mathematics component in Examinations of Zambian Biology ' $\mathrm{O}$ ' level has reduced as compared to International Biology 'O' level Edexcel (GCSE) and Cambridge (IGCSE) and whether the syllabi are similar.

2. To investigate the factors causing the reduction of mathematics component in Biology ' $O$ ' level examinations. 3. To find out the impact of reducing mathematics component in Biology ' $\mathrm{O}$ ' level examinations on students' performance in mathematical biology related courses at diploma level.

\subsection{Research methodology}

The study was conducted in Mansa District, of Luapula Province with Mansa School of Nursing and Zambia College of Open and Distance Learning offering Diploma courses. Mixed research design was adopted which involves both qualitative and quantitative data which enables determination descriptive statistics as well as relation between variables. Causal comparative research design was carried to two institutions because in this design comparisons of groups are based on a desired attributes or characteristics of interest and the factors are already known.

\subsection{Sampling design and sample size}

Judgemental sampling was used to select colleges because the characteristic of interest in the research was known and these were the distance students who did biology "O" Level with more mathematics component and the fulltime students who did less. The examination results analysis of biology education at diploma level from these selected institutions were collected to compare their mean performance in mathematical related biology courses. 200 Educational and Paramedical students were selected and this encompassed two sub categories of students' (full time students and distance students) because distance students did biology "O" level with more mathematics component as compared to full time students all of them completed school before 2008. The assessment test involving mathematical biology questions were also given and analysed.

\subsection{Data collection}

Primary data was collected using five point Likert scale questionnaire to find the factors that caused the reducing of mathematics component in Zambian biology "O" Level for teachers and examiners, an assessment test for students in mathematical biology was used to compare the mean performance of distance and full-time students. Secondary data was obtained from biology "O" Level examination question papers for the three examining boards Zambian, Cambridge and Edexcel from 1999-2017, syllabi for biology "O" Level and examination results for mathematical biology courses from Mansa School of Nursing and Zambia College of Distance and Open Learning.

\subsection{Data analysis}

Data was analysed using, Statistical Package for Social Sciences (SPSS V16) and Excel. Independent Sample ttest was used to compare the means.

\subsection{Research findings and discussions}

The first objective of the study was to find the percentage reduction in mathematics component in Zambian and international Biology ' $\mathrm{O}$ ' level examinations and the similarity of the three syllabi.

For that, biology "O" Level examination papers from 1999-2017 was checked for total percentage marks for mathematics component questions in each year and the result is shown separately in table 3.1 and table 3.2 


\begin{tabular}{|c|c|c|c|c|c|c|c|c|c|c|}
\hline Table & \multicolumn{2}{|c|}{ percentage } & for & \multicolumn{2}{|c|}{ mathematical } & related & biology & questions & \multirow{2}{*}{\multicolumn{2}{|c|}{$\frac{(1999-2007)}{2007 \text { Average }}$}} \\
\hline Year & 1999 & 2000 & 2001 & 2002 & 2003 & 2004 & 2005 & 2006 & & \\
\hline $\mathrm{ECZ}$ & 11.30 & 15 & 8.80 & 12.50 & 7.50 & 8.80 & 7.50 & 0 & 5 & 8.50 \\
\hline Edexcel & 15 & 17.50 & 18.80 & 12.50 & 13.80 & 12.50 & 13.80 & 23.80 & 12.50 & 17.30 \\
\hline Cambridge & 16 & 14 & 20 & 13 & 19 & 14 & 17 & 17 & 26 & 15.60 \\
\hline
\end{tabular}

Source: Examinations Council of Zambia (ECZ), Cambridge (IGCSE) and Edexcel (GCSE).

Table 3.2: Percentage marks for mathematical related biology questions $(2008-2017)$

\begin{tabular}{|l|l|l|l|l|l|l|l|l|l|l|l|}
\hline Year & $\underline{\mathbf{2}} 008$ & 2009 & 2010 & 2011 & 2012 & 2013 & 2014 & 2015 & 2016 & 2017 & Average \\
\hline ECZ & 0 & 7.50 & 2.50 & 2.50 & 3.80 & 5 & 3.80 & 3.80 & 5 & 2.50 & 3.60 \\
\hline Edexcel & 17 & 20 & 12 & 13 & 28 & 17 & 14 & 15 & 17 & 19 & 17.20 \\
\hline Cambridge & 13.80 & 12.50 & 13.80 & 12.50 & 16.30 & 12 & 22.50 & 17.50 & 13.80 & 16.30 & 15.40 \\
\hline
\end{tabular}

Source: Examinations Council of Zambia (ECZ), Cambridge (IGCSE) and Edexcel (GCSE).

The average percentage marks in mathematical related biology questions in these examining bodies before 2008 and after 2007 is shown in Fig (3.1)

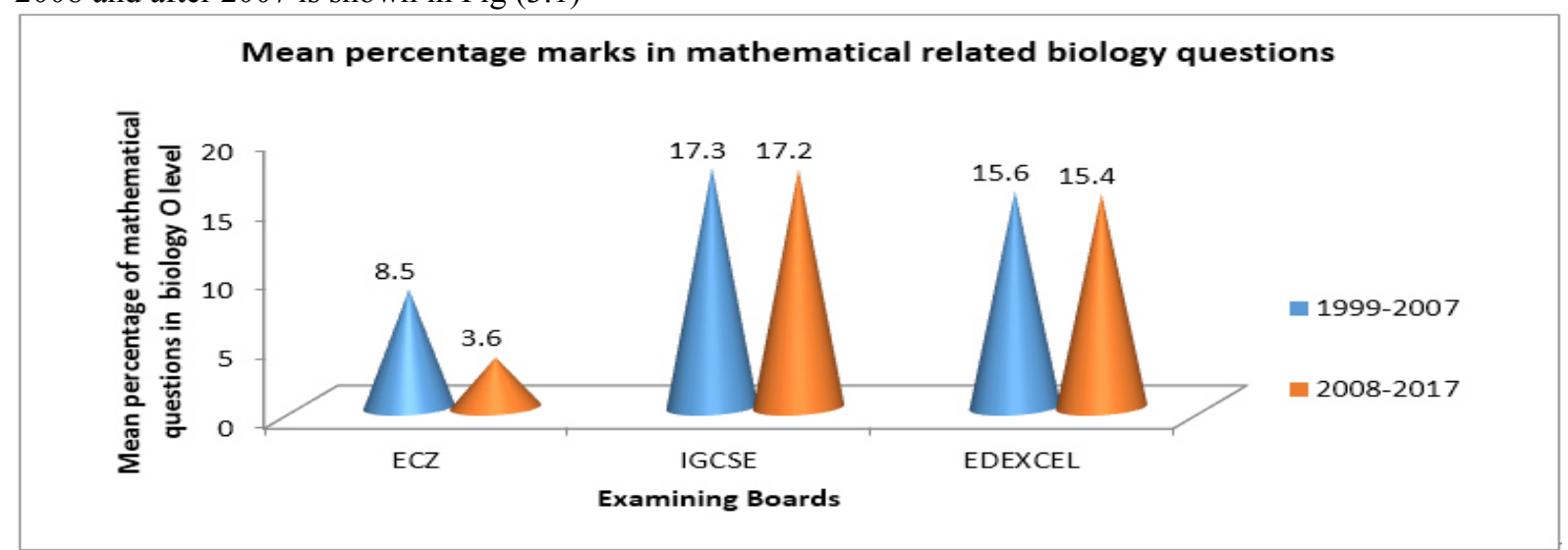

Fig (3.1) Average percentage marks in mathematical related biology questions in ECZ, IGCSE and EDEXCEL

From Fig (3.1) it is clearly seen that mathematics component in Zambian biology "O" Level has reduced more from 2008-2017. The mean mark from 1999-2007 was $8.5 \%$ while 2008 to 2017 it dropped to $3.6 \%$. There was a reduction of $57.6 \%$ in mathematical related biology "O" Level questions in Zambian whilst in Edexcel and in Cambridge the reduction was $0.60 \%$ and $1.30 \%$ respectively which were minimal.

The reduction percentage for Zambian biology "O" Level to be higher than Edexcel (GCSE) and Cambridge (IGCSE) implies that a Zambian pupil is disadvantaged in quantitative biology and will lack mathematical interpretation of biology if he/she happens to study modern biology which has more mathematics component as a career.

After analysing the key aims of biology and assessment objectives for each syllabus it was discovered that the key subject aims and assessment objectives for all the three syllabi were just the same. In Zambian syllabus there is no specification for weighting in mathematics biology component compared to the other two examining bodies. The analysis is presented in Table 3.3.

Table 3.3 Assessment aims and objectives of the 3 different examining bodies

\begin{tabular}{|c|c|c|c|c|}
\hline Zambian (CDC) & $\begin{array}{l}\text { Cambridge } \\
\text { (IGCSE) }\end{array}$ & Weightings & Edexcel (GCSE) & eightings \\
\hline $\begin{array}{l}\text { (1). Knowledge with } \\
\text { understanding. }\end{array}$ & $\begin{array}{l}\text { AO1.Knowledge } \\
\text { and understanding. } \\
\text { AO2. Handling }\end{array}$ & $50 \%$ & $\begin{array}{l}\text { AO1.Knowledge } \quad \text { and } \\
\text { Understanding. }\end{array}$ & $\begin{array}{l}(45 \%- \\
50 \%)\end{array}$ \\
\hline $\begin{array}{l}\text { (2).Handling information } \\
\text { and solving problems. }\end{array}$ & $\begin{array}{l}\text { information and } \\
\text { problem solving. } \\
\text { AO3.Experimental }\end{array}$ & $(30 \%)$ & $\begin{array}{l}\text { AO2. Application of } \\
\text { knowledge and } \\
\text { understanding, analysis }\end{array}$ & $\begin{array}{l}(27.5 \%- \\
32.5 \%)\end{array}$ \\
\hline $\begin{array}{l}\text { (3). Experimental skills and } \\
\text { investigations. }\end{array}$ & $\begin{array}{l}\text { skills and } \\
\text { investigations. }\end{array}$ & $(20 \%)$ & $\begin{array}{l}\text { and evaluation. } \\
\text { AO3. Experimental skills, } \\
\text { analysis and evaluation of } \\
\text { data and methods. }\end{array}$ & $\begin{array}{l}(20 \%- \\
25 \%)\end{array}$ \\
\hline
\end{tabular}

Source: Syllabi for CDC, Cambridge and Edexcel 
For example, assessment objective 2: Handling information and problem solving for Zambian syllabi weighting is not specified, Cambridge is $30 \%$ and for Edexcel $27.5 \%-32.5 \%$ which gives an average of $30 \%$ as well. The Zambian syllabus has shown in a small way why there is less mathematics component in the examination papers because the syllabi guides the teachers on what to teach.

The big question is how will the learners be prepared to study biology beyond "O" Level and enable them to acquire sufficient understanding and knowledge to become confident students in mathematical related biology courses like biostatistics in a changing world or able to take or develop interest in matters of scientific importance as stated in the key aims if they are not exposed to a lot mathematics component.

The second research question was to find out the factors that caused the reducing of mathematics component in biology ' $\mathrm{O}$ ' level examinations. This was achieved from the five point Likert scale questionnaire to teachers and examiners and the analysis of the data is presented in Table 3.4

Table 3.4: Responses of teachers and examiners

\begin{tabular}{|c|c|c|c|c|c|c|}
\hline & $\mathrm{SA} / 5$ & $\mathrm{~A} / 4$ & $\mathrm{U} / 3$ & $\mathrm{D} / 2$ & $\mathrm{SD} / 1$ & Mean \\
\hline $\begin{array}{l}\text { (1). Reducing of maths component in biology "O" Level } \\
\text { examinations has an effect on students" performance in biology } \\
\text { related courses at diploma level }\end{array}$ & 20 & 12 & 2 & 6 & 10 & 3.5 \\
\hline $\begin{array}{l}\text { (2). Integration of mathematics and biology will improve } \\
\text { performance in maths component at diploma level. }\end{array}$ & 20 & 15 & 0 & 10 & 5 & 3.7 \\
\hline $\begin{array}{l}\text { (3). Negative attitude of pupils in answering maths related questions } \\
\text { in biology "O" level had led to the reducing of maths component in } \\
\text { biology "O" level. }\end{array}$ & 20 & 12 & 2 & 5 & 11 & 3.5 \\
\hline $\begin{array}{l}\text { (4). Poor performance of pupils in maths component in biology "O" } \\
\text { Level has led to the reducing of maths component in biology "O" } \\
\text { Level }\end{array}$ & 15 & 20 & 5 & 6 & 4 & 3.7 \\
\hline $\begin{array}{l}\text { (5).Failure rate of pupils in biology "O" Level led to the reducing } \\
\text { of maths component in biology "O" Level }\end{array}$ & 20 & 10 & 3 & 5 & 12 & 3.4 \\
\hline $\begin{array}{l}\text { (6)Mathematical challenges faced by biology teachers led to the } \\
\text { reducing of maths component in biology "O" Level }\end{array}$ & 2 & 5 & 0 & 20 & 23 & 1.9 \\
\hline $\begin{array}{l}\text { (7) Incompetence of biology teachers in maths because of not being } \\
\text { well trained in maths component in biology led in not supporting } \\
\text { teaching of more maths component in biology "O" Level. }\end{array}$ & 2 & 9 & 10 & 12 & 17 & 2.3 \\
\hline $\begin{array}{l}\text { (8)The amount of teaching maths component in Zambian biology } \\
\text { "O" Level is less as compared to International biology "O" Level } \\
\text { Edexcel and Cambridge. }\end{array}$ & 6 & 2 & 30 & 2 & 10 & 2.8 \\
\hline
\end{tabular}

Source: Field data Key: SA - Strongly Agree, A - Agree, U - Undecided, D - Disagree, SD - Strongly Disagree

From the analysis of the questionnaire the researcher discovered the following: The attitude and performance of pupils in mathematical related questions in biology "O" Level, and the failure rate of the pupils in biology "O" Level led to the reducing of mathematics component in biology "O" Level this is in agreeing of the findings of Elizabeth B et al (2017) and Kirima (2000).

The respondents disagreed that the mathematical challenges faced by biology teachers and their incompetence in mathematics because of not being well trained in mathematics component in biology had led in support of not teaching more mathematics component in biology "O" Level. But on the contrary it contradicts with the findings of Kirima (2000) who blamed the teachers.

The study also revealed that the integration of mathematics "O" Level and biology "O" Level is going to improve performance in mathematics component at diploma level this is in agreeing of the findings of Campbell et al., 2006; Metz, 2008; Arnett and Van Horn, 2009; McEwen et al., 2009; Pursell, 2009; Elizabeth B et al (2017). The respondents were undecided whether the amount of teaching mathematics component in Zambian biology "O" Level is less as compared to the other two examining boards.

The last objective was to find out the impact of reducing mathematics component in Biology ' $O$ ' level examinations on students' performance in mathematical biology related courses at diploma level. For that an assessment test involving mathematical related biology questions from the diploma level were given to both group of students and the results are shown in Table 3.5

Table 3.5 Assessment test Performance for distance and fulltime students.

\begin{tabular}{llllllll}
\hline Groups & $\mathrm{N}$ & Mean score $\%$ & $\mathrm{SD}$ & Mean Difference & $\mathrm{df}$ & t-value & $\mathrm{p}$-value \\
\hline Distance & 100 & 60.25 & 13.442 & 6.44 & 198 & 0.001 & 0.421 \\
Full time & 100 & 53.81 & 11.552 & & & & \\
Total & 200 & & & & & & \\
\hline
\end{tabular}

Source: SPSS output. 
From the test result the mean performance of students who did biology "O" level with more mathematics was $60.25 \%$ while that for students with less mathematics was $53.81 \%$. There was a mean difference of $6.44 \%$ between these two groups of students. $\mathrm{P}=0.421>\alpha=0.05$ implied that equal variances of the two groups were assumed. This was Levenes test for equality of variances as it is also an assumption for conducting Independent Sample t- test. The significant value was 0.001 which was less than $\alpha$ value 0.05 , hence there was a significant difference between the performance of distance students and full time students in mathematical related biology courses at diploma level.

Further, the examination results analysis of biology education at diploma level from these two institutions was collected for three intakes (2006,2015and 2016) and compared their mean performances in mathematical related biology courses and the results are shown in Table 3.1.

Table 3.1 Analysis of examination results of diploma students

\begin{tabular}{ll}
\hline Groups & Mean score \% \\
\hline Students with more Mathematical component & 60.08 \\
Students with less mathematical component & 53.78 \\
\hline
\end{tabular}

\section{Source: Field data}

From Table (3.1) it is seen that distance students (before 2008) performed better than fulltime (after 2007) students with the mean difference of $6.30 \%$.

Conclusively, the reducing of mathematics component in biology " $O$ " Level had a negative impact on the performance of students studying mathematical biology related courses at diploma level and there was significant difference in performance between the students those who did biology "O" Level with more mathematics component (before 2008) and those who did with less mathematics component (after 2007) at $\alpha$ value 0.05.

\subsection{Conclusion and recommendations}

This study has revealed that the international examinations biology "O" Level, Cambridge (IGCSE) and Edexcel (GCSE) is different from Zambian biology "O" Level (ECZ), Mathematics component in International biology "O" Level examinations was more and that it has been consistent from 1999 to 2017 whilst in (ECZ) biology "O" Level examinations it was less and has kept on reducing from 2008 to 2017. Comparisons of Zambian syllabi (CDC) and International syllabi Cambridge (IGCSE) and Edexcel (GCSE) revealed that the syllabi had similar key aims and assessment objectives except for assessment objective weightings which Zambian syllabi never had. The questionnaire also revealed that the attitude and performance of pupils in mathematics related biology questions and their failure rate in Zambian biology "O" Level were the factors revealed by the study to have led to the reduction of mathematics component in biology "O" Level.

The assessment test that was given to the students showed that reducing of mathematics component in biology "O" Level had a negative impact on student's performance in mathematical related biology courses at diploma level. The study revealed that the-students who did biology "O" Level with more mathematics component performed better than the ones who did with less mathematics component in both examinations and assessment test.

The following are suggestions and recommendations:

The Ministry of General Education should engage the Curriculum Development Centre and The Examinations Council of Zambia so as to harmonise the syllabi and the setting of examinations in biology "O" Level because the examinations should be a true reflection of the syllabus which is not the case as discovered in the study. The assessment objectives should have the specific weightings so as to guide the biology teachers as well as the pupils. The curriculum specialists for biology "O" level (5090) should ensure that there are more questions involving mathematics components in biology "O" Level so that pupils will have pre-requisite knowledge to help them at higher level. The Examinations should be a true reflection of the demand of the syllabi and the changing world

\section{References}

Cambridge International Examinations, 2014. Syllabus Cambridge IGCSE Biology, 0610. University of Cambridge, London, UK.

Cambridge International Examinations CLEAPSS Laboratory Handbook, updated in 2009, UK regulations.

Curriculum Development Centre, 2013. Biology Syllabus, Grade 10 to 12, Ministry of Education, Science, Vocational Training and Early Education, Lusaka, Zambia.

Ford, M. (2008). Disciplinary authority and accountability in scientific practice and learning. Science Education, 92(3), 404-423.

Hardy K, Stark J. Mathematical models of the balance between apoptosis and proliferation. Apoptosis. 2002;7:373-81.

Junch R (2007). Ten Equations That Changed Biology: Mathematics in Problem Solving Biology Curricula. 
Oxford University Press UK.

Kirima K. (2005). Nitrite is an alternative source of No in vivo.

Komarova NL. Cancer, aging and the optimal tissue design. Semin Cancer Biol. 2005; 15:494-505.

Ministry of Education, Science Vocational Training and Early Education prepared and published by the Curriculum Development Centre, Lusaka - Zambia 2013

Murray J.D. (2003). Mathematical Biology. Springer - Veriag 3rd Ed: Cambridge University Press. Cambridge.

'Exploring factors affecting... (PDF Download Available). Available from:
https://www.researchgate.net/publication/267515216\%27Exploring_factors_affecting_performance_in_Bi ology_5090_at_selected_high_schools_in_Lesotho\%27 [accessed May 05 2018]. 